\title{
A comparison between spectrophotometric and titrimetric methods of estimating trypsin ${ }^{1}$
}

\author{
H. SACKS, S. BANK, I. KRAMER, B. NOVIS, AND I. N. MARKS \\ From the Gastro-Intestinal Clinic, Groote Schuur Hospital, and Department of Medicine, University of Cape \\ Town, South Africa
}

SUMMARY The spectrophotometric method described is quick and effective and a reliable alternative to a titrimetric method for measuring trypsin activity in duodenal juice.

A spectrophotometric method for the determination of trypsin activity in duodenal juice was suggested by Schwert and Takenaka in 1955, and a modification of this method was later described by Lundh (1957). Other methods involve the use of a $p \mathrm{H}$ stat. automatic titrator (Haverback, Dyce, Gutentag, and Montgomery, 1963) and a $p \mathrm{H}$ meter (Wiggins, 1967). In this paper, the method of Schwert and Takanaka, as modified by Seravac Laboratories, is compared with the titrimetric ( $p \mathrm{H}$ meter) method described by Wiggins (1967).

\section{Materials}

Over a period of two months, 50 consecutive samples of duodenal juice were analysed for trypsin activity by spectrophotometric and titrimetric methods. The samples were taken fresh and at random from patients referred for pancreatic function tests using the method of separate gastric and duodenal intubation and pancreatic stimulation by secretin followed by pancreozymin (Bank, Marks, Moshal, Efron, and Silber, 1963).

\section{Methods}

\section{SPECTROPHOTOMETRIC METHOD}

Principle

The specific substrate, N-benzoyl-L-arginine ethyl hydrochloride (BAEE) in phosphate buffer $p \mathrm{H} \mathrm{8.0}$ is hydrolysed in the presence of trypsin at the ester linkage and this hydrolysis causes an increase in optical density at $253 \mathrm{M} \mu$. One unit of activity is that activity which causes an increase in optical density at $253 \mathrm{M} \mu$ of 0.001 per minute under the standard conditions. Allowing for dilution factor,

${ }^{1}$ This study was supported by the Medical Research Council of South Africa and University of Cape Town staff research fund.

Received for publication 7 July 1971. time of assay, and volume, results are expressed in BAEE units/ml juice/minute. For conversion to international units, ie, $\mu \mathrm{moles} / \mathrm{min} / \mathrm{ml}$ duodenal juice, see the calculation below.

\section{Apparatus}

Beckman D.B. model spectrophotometer.

\section{Reagents}

1 BAEE

$20.001 \mathrm{~N} \mathrm{HCl}$

$30.05 \mathrm{M}$ phosphate buffer, prepared as follows: (a) $7.8 \mathrm{~g} \mathrm{NaH}_{2} \mathrm{PO}_{4} 2 \mathrm{H}_{2} \mathrm{O}-1$ litre and (b) $7 \cdot 1 \mathrm{~g}$ $\mathrm{Na}_{2} \mathrm{HPO}_{4}-1$ litre. Mix $(a)$ and $(b)$ to $p \mathrm{H} 8$.

4 Substrate is obtained by mixing $8.6 \mathrm{mg}$ BAEE with $100 \mathrm{ml}$ phosphate buffer, giving a $0.00025 \mathrm{M}$ solution.

\section{Procedure}

Pancreatic juice and dilution tubes are always kept on ice.

Dilute pancreatic juice with $0.001 \mathrm{~N} \mathrm{HCl}$, initially 1 in 5 , increasing to 1 in 40 , if necessary, with separate samples. A dilution of 1 in 5 applies to low enzyme activity, 1 in $\mathbf{4 0}$ for normal.

Place the following in the cuvettes at $25^{\circ} \mathrm{C}$ :-

\begin{tabular}{llll}
\hline & Test & Control $(S)$ & Reference $(R)$ \\
\hline Substrate $(\mathrm{ml})$ & 3.0 & 3.0 & 3.0 \\
0.001 N HCl $(\mathrm{ml})$ & - & 0.2 & - \\
Juice solution $(\mathrm{ml})$ & 0.2 & - & - \\
\hline
\end{tabular}

Set machine at $253 \mathrm{M} \mu$. If the double beam is used, place the reference cuvette in ' $R$ ' and leave it there during the test. With the control adjust the optical density to read $0 \cdot 05$. Set the recorder correspondingly.

Add enzyme to substrate and start the graph at once. Let the recorder run for five minutes, taking the reading over a three-minute slope. 
The machine is reset at 0.05 with each assay and the graph is reset.

Each assay is repeated. A $5 \%$ error is arbitrarily accepted.

A standard with crystalline trypsin of known activity is assayed with each test.

\section{Calculation}

Let $1 / D=$ dilution used

$\frac{E_{253}}{3}=$ change in optical density per minute at wavelength $253 \mathrm{~m} \mu$

Result in BAEE units $/ \mathrm{min} / \mathrm{ml}=\frac{5 \mathrm{D} \times \mathrm{E}_{253}}{3 \times 0.001}$

Result in $\mu \mathrm{moles} / \mathrm{min} / \mathrm{ml}$ duodenal juice (international units) can be expressed: $\frac{5 \mathrm{D} \times \mathrm{E}_{253}}{3} \times \frac{1}{359}$ according to the following data (Trautschold and Werle, 1957; Rick, 1956).

The optical density difference between $10^{-3} \mathrm{M}$ solution of N-benzoyl-L-arginine and the ethyl ester is 1.15 at $25^{\circ} \mathrm{C}, p \mathrm{H} 8.0$, and with a $1 \mathrm{~cm}$ light path. With a volume of $1 \mathrm{ml}$ an optical density change of $+1 \cdot 15 / \mathrm{min}$ corresponds to the conversion of $1 \mu$ mole of substrate/minute. With a $3.2 \mathrm{ml}$ assay volume the reaction of $1 \mu \mathrm{mole}$ of substrate/min is equivalent to an increase in optical density of $0 \cdot 359 /$ minute.

TITRIMETRIC METHOD

The method of Wiggins (1967) was used.

\section{Results}

Each result constitutes the mean of two readings. Figure 1 shows a comparison of the results by the two methods. Two points coincided on the computerized graph (Fig. 1), this accounting for the 48 marked points of the 50 results. The correlation coefficient was 0.84 . The wider scatter at values greater than $11.2 \mu \mathrm{moles} / \mathrm{min} / \mathrm{ml}\left(4 \times 10^{3}\right.$ BAEE units) and $30 \mu$ equiv $/ \mathrm{min} / \mathrm{ml}$ is of minor importance as most of our abnormal results are less than 8.3 $\mu \mathrm{moles} / \mathrm{min} / \mathrm{ml}\left(3 \times 10^{3}\right.$ BAEE units), particularly in post-pancreozymin samples.

\section{Discussion}

The spectrophotometric method does not appear to be widely used. However, the statistically significant degree of correlation with the titrimetric method

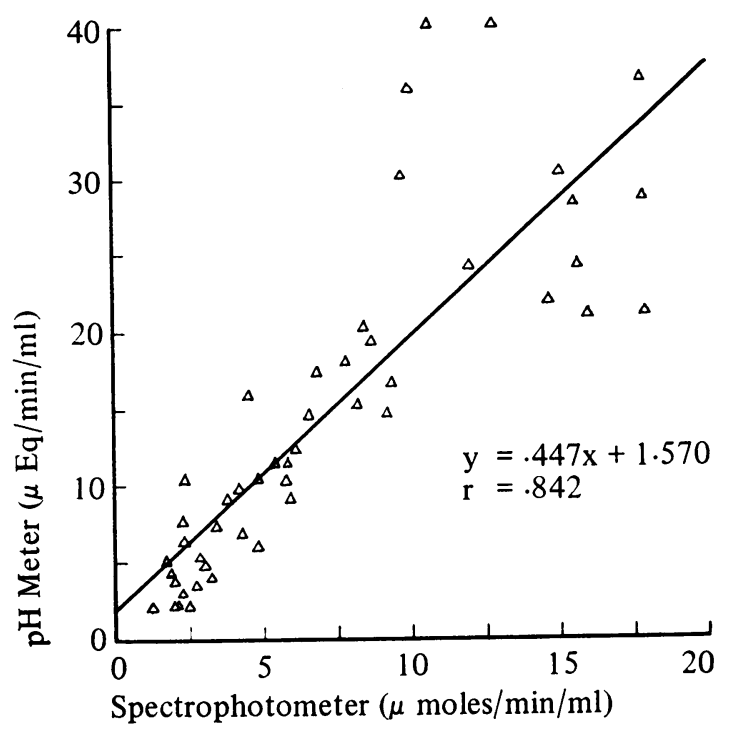

Fig. 1 Graphic comparison of results.

shows that it is an effective alternative for trypsin estimation. In a laboratory such as ours, where the demand for this estimation is frequent, the spectrophotometric method permits a rapid yield of results for fresh specimens while the patient is having the pancreatic function test, it is technically simple to do, and economizes by using less of an expensive substrate. It must be stressed, however, that owing to the turbidity of samples obtained after a Lundh test meal, the spectrophotometric method is unsuitable.

We thank Professor E. Dowdle, Dr M. Berelowitz, and Dr W. Gevers for their assistance in the computer analysis and calculations.

\section{References}

Bank, S., Marks, I. N., Moshal, M. G., Efron, G., and Silber, R. (1963). The pancreatic-function test. Method and normal values. S. Afr. med. J., 37, 1061-1066.

Haverback, B. J., Dyce, B. J., Gutentag, P. J., and Montgomery, D. W. (1963). Measurement of trypsin and chymotrypsin in stool: a diagnostic test for pancreatic exocrine insufficiency. Gastroenterology, 44, 588-597.

Lundh, G. (1957). Determination of trypsin and chymotrypsin in human intestinal content. Scand. J. clin. Lab. Invest., 9, 229-232.

Rick, W. (1956). Unpublished data. In Methods of Enzymatic Analysis, edited by H. U. Bergmeyer, pp. 818-828. Academic Press, New York and London.

Schwert, G. W., and Takenaka, Y. (1955). A spectrophotometric determination of trypsin and chymotrypsin. Biochim. biophys. Acta (Amst.), 16, 570-575.

Trautschold, I., and Werle, E. (1961). Hoppe-Seylers Z. physiol. Chem. 325, 48-59.

Wiggins, H. S. (1967). Simple method for estimating trypsin. Gut, 8, 415-416. 